\title{
Antigen of Haemophilus influenzae in bronchial tissue
}

\author{
CHRISTOPHER W CLARKE, CATHERINE A HANNANT, RALPH SCICCHITANO, \\ KEN J DONALD, BARRY JACKSON
}

From the Respiratory Investigation Unit, The Prince Charles Hospital, Chermside, and

Department of Pathology, Royal Brisbane Hospital, Brisbane, Queensland, Australia

ABSTRACT Haemophilus influenzae antigen was detected in five of seven bronchial biopsies obtained from patients undergoing diagnostic bronchoscopy. Antibody against $H$ influenzae antigens was obtained from a patient with bronchiectasis. Immunofluorescent techniques were used. This provides further evidence to support the pathogenicity of $H$ influenzae in lower respiratory tract disorders.

Haemophilus influenzae has been incriminated by a variety of indirect methods, including sputum culture, detection of antibody in serum and sputum, and response to antibiotic therapy, as a pathogen in chronic bronchitis, cystic fibrosis and

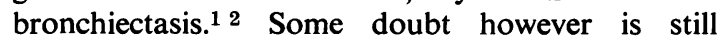
expressed about its true significance in sputum cultures from patients with these diseases. 34

Direct evidence of tissue invasion by $H$ influenzae might prove to be more convincing evidence of pathogenicity. This is particularly relevant as a number of reactions have been induced by antigens of $H$ influenzae which could contribute to the pathogenesis of these conditions. These are bronchoconstriction after antigen challenge, ${ }^{5}$ positive skin test reactions, ${ }^{6}$ release of histamine from nonsensitised human lung and leucocytes, ${ }^{6}$ and inhibition of ciliary activity. ${ }^{?}$

The purpose of this study was to determine if antigen derived from $\boldsymbol{H}$ influenzae could be detected in the bronchial tissue of patients with lower respiratory tract disease.

\section{Methods}

\section{ANTIBODY}

Antibody for testing was prepared from the serum obtained from a female patient with bronchiectasis. This patient had been found to have precipitating antibody detected by immunodiffusion to heat stable and heat labile antigens of Haemophilus influenzae. ${ }^{8}$ Antibody to the heat labile antigens was shown to react to the fraction specific to $H$ influenzae. ${ }^{9}$ Precipitin reactions to the above antigens were present at a $1 / 20$ and $1 / 100$ dilution of the patient's serum respectively. The immunoglobulin fraction

Address for reprint requests: Dr CW Clarke, PO Box 310, Eastwood, NSW 2122, Australia. was then precipitated out using standard ammonium sulphate fractionation procedures followed by column separation with Whatman's DEAE cellulose 52. The antibody activity was detected in the first peak coming off the column indicating it was predominantly IgG. This fraction was then freeze-dried. For testing, the freeze-dried material was reconstituted at a concentration of $12.5 \mathrm{~g} / \mathrm{l}$ with phosphate buffered saline.

\section{BRONCHIAL TISSUE}

This material was obtained at fibreoptic bronchoscopy performed under general anaesthetic in patients requiring this procedure for diagnostic purposes. Informed consent had been obtained and the study was approved by the Hospital's Ethics Committee. Clinical details, sputum culture results, and precipitin reactions to $H$ influenzae antigens were obtained before the procedure. Immediately after biopsy the specimens were wrapped in silver foil and snap frozen in liquid nitrogen.

\section{IMMUNOFLUORESCENCE OF BRONCHIAL} BIOPSIES

Frozen sections of the bronchial tissue were cut and air dried for 15 minutes. They were then washed in two changes of phosphate buffered saline $(\mathrm{NaCl}-$ $42.5 \mathrm{~g}, \mathrm{Na}_{2} \mathrm{HPO}_{4}-5.35 \mathrm{~g}, \mathrm{Na}_{2} \mathrm{HPO}_{4}-1.95 \mathrm{~g}$, distilled water-5 litres) (PBS) for five minutes each wash. (1) The first slide was then stained by covering the sections with $H$ influenzae anti-serum $(12.5 \mathrm{~g} / \mathrm{l})$ for 25 minutes, washing in two changes PBS for five minutes each, then flooding the slide with fluorescein labelled anti-human IgG (sheep) dilution 1 in 10 for 25 minutes. After two more washes in PBS the preparation was then mounted in a PBS/glycerol solution. (2) The second slide was stained with fluorescein labelled anti-human IgG (sheep) for 25 
Table Details of patients biopsied

\begin{tabular}{|c|c|c|c|c|c|c|c|}
\hline \multirow[t]{2}{*}{ Patient } & \multirow{2}{*}{$\begin{array}{l}\text { Age at } \\
\text { biopsy } \\
(y r)\end{array}$} & \multirow[t]{2}{*}{ Sex } & \multirow[t]{2}{*}{ Diagnosis } & \multirow[t]{2}{*}{ Smoking history } & \multirow[t]{2}{*}{ Sputum culture } & \multicolumn{2}{|c|}{ Precipitins } \\
\hline & & & & & & Protein & Polysaccharide \\
\hline 1 & 59 & $\mathbf{M}$ & $\begin{array}{l}\text { Chronic bronchitis } \\
\text { Carcinoma of lung }\end{array}$ & $\begin{array}{l}2 \text { ounces tobacco a week for } \\
40 \text { years }\end{array}$ & Strep pneumoniae & + & + \\
\hline 2 & 55 & $\mathbf{M}$ & Carcinoma of lung & 60 a day for 30 years. Stopped 1970 & - & + & + \\
\hline 3 & 44 & $\mathbf{M}$ & Resolving pneumonia & 30 a day & - & - & - \\
\hline 4 & 69 & $\mathrm{~F}$ & Carcinoma of lung & 20 a day for 53 years & - & NT & NT \\
\hline 5 & 60 & $\mathbf{M}$ & $\begin{array}{l}\text { Chronic bronchitis } \\
\text { Carcinoma of lung }\end{array}$ & 30 a day. Stopped 1969 & $S$ aureus & - & 一 \\
\hline 6 & 63 & $\mathbf{M}$ & Carcinoma of lung & 20 a day & - & - & 一 \\
\hline 7 & 68 & $\mathbf{M}$ & $\begin{array}{l}\text { Chronic bronchitis } \\
\text { Carcinoma of lung }\end{array}$ & 60 a day & - & - & - \\
\hline
\end{tabular}

$\mathrm{NT}=$ not tested.

minutes, washed in two changes PBS, and mounted. (3) The third slide was stained with anti-human IgG (sheep), washed in two changes of PBS, then stained with fluorescein labelled anti-human IgG (sheep) for 25 minutes, washed again in two changes of PBS, and mounted. (4) The fourth slide used as a negative control was left in PBS for $\mathbf{3 0}$ minutes then mounted. The preparations were then examined under ultraviolet light and photographed.

Similar tests were performed using fluorescein labelled sheep anti-human $\operatorname{IgA}, \operatorname{IgM}, \operatorname{IgE}, \mathrm{C}_{3}$, and fibrinogen (Wellcome Reagents Ltd).

\section{Results}

Seven patients had bronchial biopsies performed during routine fibreoptic bronchoscopy. Details of the patients are summarised in the table. Sputum produced at the time of study was mucoid and scanty in all cases. The patients in whom a diagnosis of chronic bronchitis had been made $(1,5$, and 7$)$ had not had a recent exacerbation.

The immunofluorescent studies gave positive results with the labelled anti-human IgG antibody in cases $1,4,5,6$, and 7; 2 and 3 were negative. Cases $1,2,6$, and 7 are illustrated (figs 1-4). The findings in cases 3,4 , and 5 were as follows.

\section{PATIENT 3}

This biopsy included bronchial epithelial and submucosal tissue. No significant staining occurred. Autofluorescence of collagen in the submucosal tissue was evident. In particular no evidence of antilung tissue staining was seen with the anti-haemophilus sera.

\section{PATIENT 4}

This biopsy included epithelium and submucosal tissue. There was constant background autofluorescence of the submucosal tissues but additional fluorescence was present after treatment with the anti-haemophilus serum.

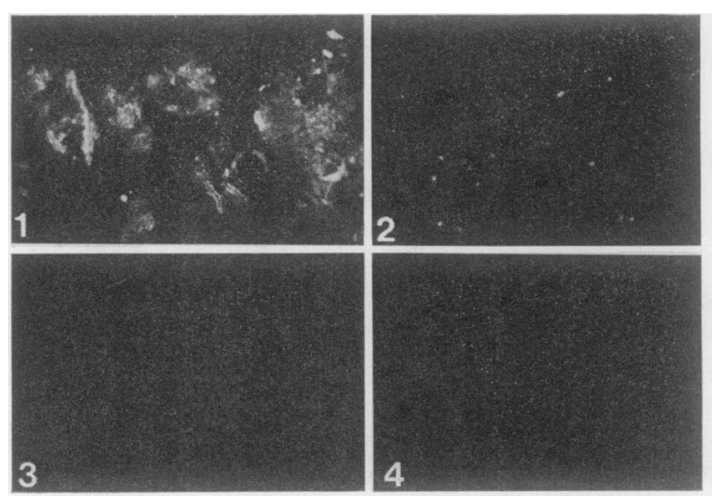

Fig 1 Patient 1. This was a superficial biopsy consisting of the epithelial layer and luminal macrophages only without any underlying bronchial wall tissue. The only staining achieved was after treatment with the antihaemophilus serum. Original magnification $\times 45$. In this and subsequent figures the numbers refer to different staining procedures as outlined in Methods-that is, (1) $H$ influenzae anti-serum followed by fluorescein labelled anti-human IgG (sheep); (2) fluorescein labelled anti-human IgG (sheep); (3) anti-human IgG (sheep) followed by fluorescein labelled anti-human IgG (sheep); (4) negative control.

\section{PATIENT 5}

This biopsy included epithelium and submucosal tissue. There was constant background autofluorescence of the submucosal tissues but additional fluorescence was present after treatment with the anti-haemophilus serum.

The common problems of autofluorescence of lung tissue and the presence of human globulin in inflammatory tissues were encountered and made photography in some cases difficult-for example, patients $3,4,5,6$, and 7 .

Studies using the remaining labelled anti-human fibrinogen were all negative. The negative staining in cases 2 and 3 after anti-haemophilus serum is 

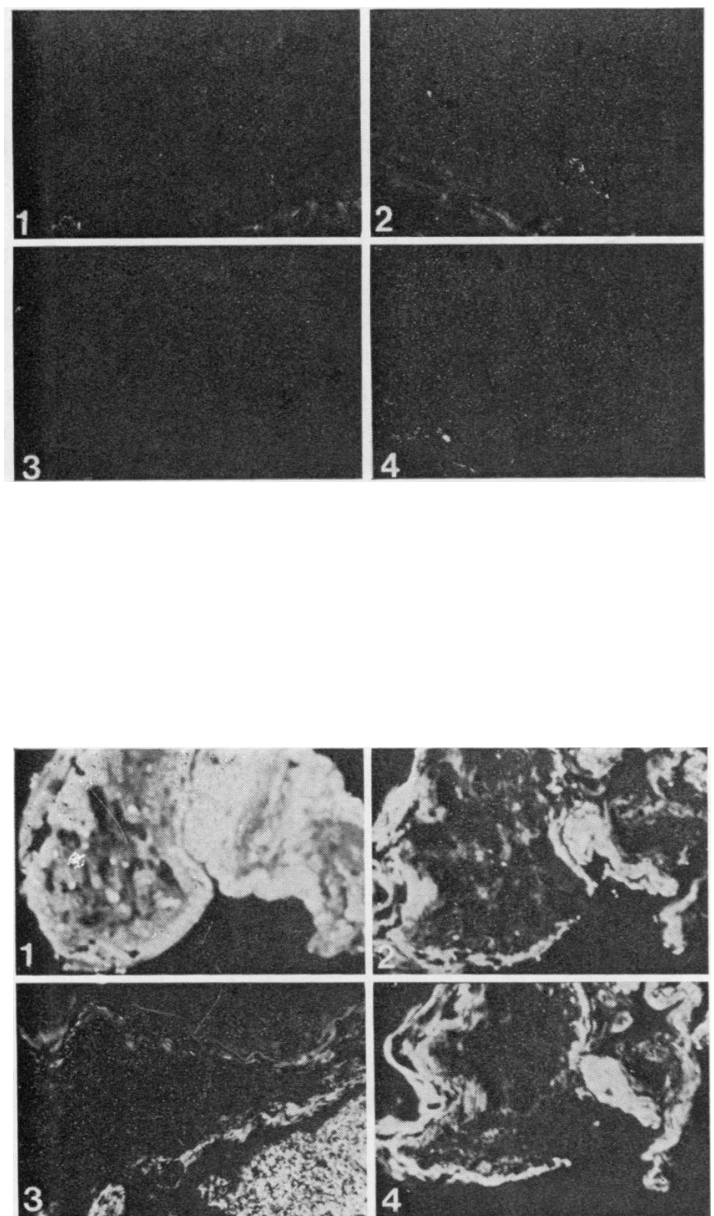

3
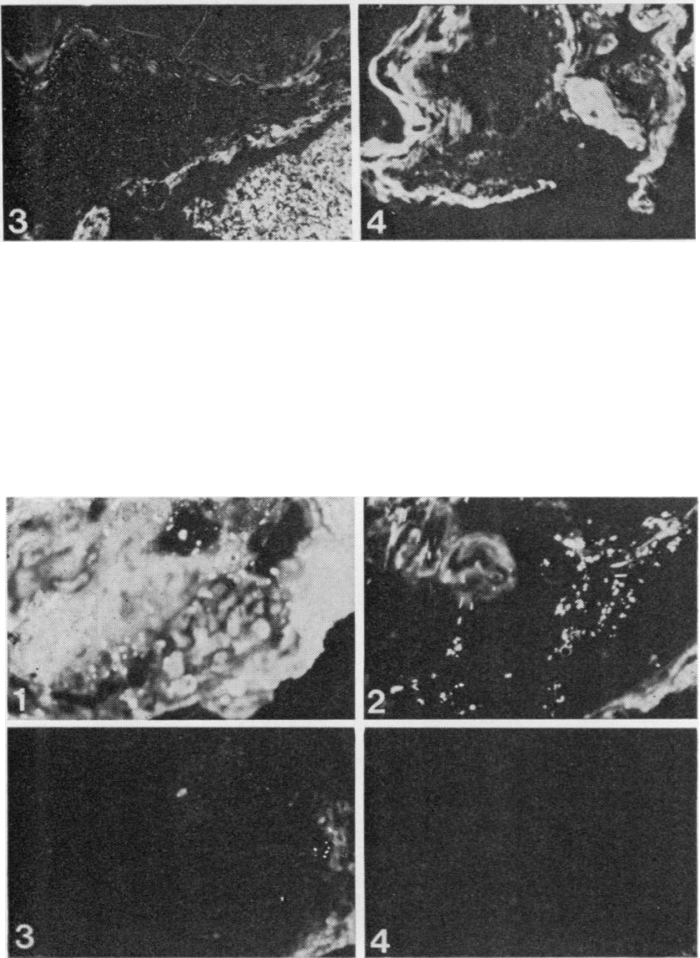

Fig 2 Patient 2. This was a superficial biopsy with small segments of basement membrane. No positive staining was obtained. In particular no evidence of anti-lung tissue staining by the anti-haemophilus serum was present. Original magnification $\times 45$.

Fig 3 Patient 6. This biopsy included epithelium and submucosal tissue. There was constant background autofluorescence of the submucosal tissues, but additional fuorescence was present after treatment with the anti-haemophilus serum. Original magnification $\times 45$.

Fig 4 Patient 7. This biopsy consistcd of epithelium and submucosal tissue. There was significantly increased staining in the IgG control and the anti-haemophilus serum treated sections. The latter was clearly the most significant staining. Original magnification $\times 45$. 
evidence that this serum does not contain anti-lung antibodies. This was confirmed by similar negative staining on a number of normal lung sections obtained from postmortem material.

\section{Discussion}

With the methods used, we feel that we were able to demonstrate antigen of $\boldsymbol{H}$ influenzae in bronchial tissue from five of seven patients including all three with a diagnosis of chronic bronchitis. None of the patients had purulent sputum at the time of the study and none of the patients with chronic bronchitis had had a recent exacerbation. This could explain the presence of antigen in bronchial tissue with the absence of the organisms in all sputum samples and precipitating antibody to $H$ influenzae antigen in one of four positive patients. One would expect to find $\boldsymbol{H}$ influenzae in this group as they all had a smoking history and this association has been described. Conversely, lifelong non-smokers have not shown a susceptibility to infection with the organism. ${ }^{10}$

It is accepted that the appearances described in the bronchial tissue could have been caused by the antibody used reacting with other antigens. To ensure specificity of the reaction, the antibody was obtained from a patient who was found to have antibody to antigens of $H$ influenzae, including those antigenic components of the organism that are regarded as specific to this organism $^{9}$ and with $H$ influenzae persistently isolated from sputum samples. The presence of anti-lung antibody in this antibody and therefore an explanation for the reactions is unlikely in view of the negative staining in two patients and in a number of normal lung sections obtained from postmortem material.

Further study is required to determine the exact location of the antigen in the bronchial wall. In particular the diffuse nature of the specific immunofluorescence requires further examination. This sug- gests that antigen liberated from bacteria is widely distributed, while the numbers of bacteria may be low. Larger pieces of tissue will be needed for this and will almost certainly have to come from operative specimens. Tissue from the bronchial trees of non-smokers and people free of respiratory symptoms will also need to be looked at.

Evidence is accumulating to support the concept of the pathogenicity of $\mathrm{H}$ influenzae in bronchial disorders. The persistence of antigen in the absence of evidence of active or recent infection suggests that the organism could exert a continuing influence after the original infection has subsided. The next step is to discover the mechanism of this pathogenicity and the part, if any, the organism plays in the initiation and progression of these disorders.

\section{References}

${ }^{1}$ May JR. The flora of the respiratory tract in chronic disease. Postgrad Med J 1975;51:144-6.

${ }^{2}$ Clarke CW. Aspects of serum and sputum antibody in chronic airways obstruction. Thorax 1976;31:702-7.

3 Tager I, Speizer FE. Role of infection in chronic bronchitis. New Engl J Med 1975;292:563-71.

4 Bell S. The relevance of bacteriology tests to the clinical use of antibiotics in domiciliary practice. $J$ Antimicrob Chemother 1976;2:110-1.

${ }^{5}$ Van der Zwan JC. Bronchial obstructive reactions and Haemophilus influenzae. Second edition. Leusden: Netherlands Asthma Fund, 1977;33.

- Clarke CW. In vivo and in vitro reactions to antigens of Haemophilus influenzae in bronchial obstruction. $\mathrm{Br} J$ Dis Chest 1979;73:373-81.

7 Denny FY. Effect of a toxin produced by $\boldsymbol{H}$ influenzae on ciliated respiratory epithelium. J Infect Dis 1974;129: 93-100.

${ }^{8}$ Clarke CW. Antigens of Haemophilus influenzae. Clin Allergy 1977;7:41-7.

${ }^{9}$ May JR. Chemotherapy of chronic bronchitis and allied disorders. Second edition. London: The English Universities Press Ltd, 1972:103-4.

${ }^{10}$ May JR, Peto R, Tinker CM, Fletcher CM. A study of Haemophilus influenzae precipitins in the serum of working men in relation to smoking habits, bronchial infection and airway obstruction. Am Rev Respir Dis $1973 ; 108: 460-8$. 